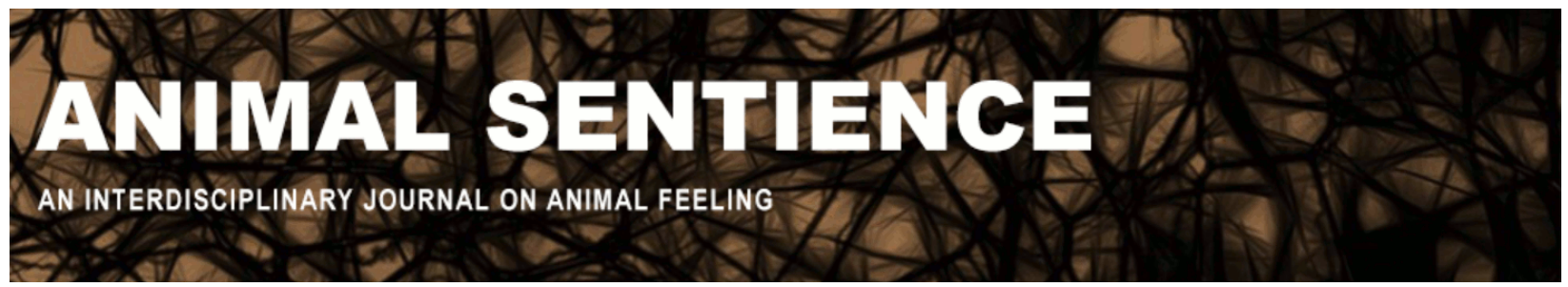

Kiley-Worthington, Marthe (2020) The wholeness of nature. Animal Sentience 27(19)

DOI: $10.51291 / 2377-7478.1542$

Date of submission: 2020-01-11

Date of acceptance: 2020-02-09

(c)

This article has appeared in the journal Animal

Sentience, a peer-reviewed journal on animal

cognition and feeling. It has been made open access,

free for all, by WellBeing International and deposited

in the WBI Studies Repository. For more information,

please contact

wbisr-info@wellbeingintl.org.

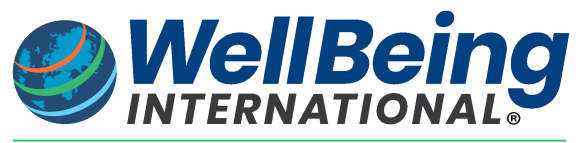

SOLUTIONS FOR PEOPLE, ANIMALS AND ENVIRONMENT 


\title{
The wholeness of nature
}

Commentary on Treves et al. on Just Preservation

\author{
Marthe Kiley-Worthington \\ Eco-Etho Research \& Education Centre, Oare, UK
}

\begin{abstract}
The target article outlines various positions on conservation and preservation but ignores practical considerations of management since there is no wild habitat left. Population controls, either human or nonhuman mammals, are not discussed. The suggestions for legal changes are vague and will require much more thinking about how to integrate animal welfare with wildlife conservation concerns. "Freedoms" as outlined in the human bill of rights might help with decision making for improving animal welfare. Other commentators have made anthropocentric judgements concerning animal welfare, ignoring the importance of developing other ways of seeing and understanding the "multiplicity within unity," combining empirical data and technological data with subjective judgement, proving crucial for survival.
\end{abstract}

Marthe Kiley-Worthington, Director, Eco Research \& Education Centre, is a specialist in the theory and practice of ecological agriculture and animal welfare for farm, companion, zoo, sanctuary and wild animals. Website

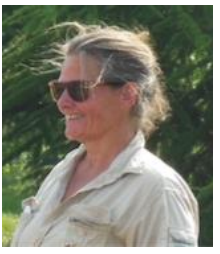

Treves et al. (2019) outline some of the positions that have been taken on conservation and preservation. On balance their target article is sensible and thoughtful, but it is tied too tightly to one branch of epistemology and empirical science, ignoring serious practical considerations about how justice can be administered. For example, nowhere in the article (or in the subsequent commentaries) is there any mention of how the size of the populations of nonhumans or humans (by far the major problem of the future) is to be controlled. If any of the "social shifts" Treves et al. discuss - such as changing the distribution of money, favouring future generations or empowering women - are to be taken seriously, these must be coupled with suggestions on how human population control can be achieved now. If this is not done, none of the ideas in the target article are going to help either "conservation" or "preservation" of the natural world.

Ecologists today, whether "conservationists" or "preservationists," are confronted daily with the problem of population control for both humans and nonhumans because there is no wild habitat left: all areas are limited by human activities. So how do you cope with controlling too many elephants in an area where they are destroying their environment, threatening the survival of other species, and there is nowhere else for them to go? Both individual interests, generally put forward by those interested in animal welfare, and species survival, often the major interest of wildlife conservation, must be taken into consideration. Both must be combined, which will give rise to different strategies in different places to ensure future sustainability, whether this is called "conservation" or "preservation." If there is to be no control of numbers, as suggested, then in the elephant example above, the area will develop "elephacentrically," favoring elephants 
above all other species, with the same problems as confronted today by "anthropocentric" development. Is this any more desirable? All populations within the now restricted areas, but particularly those of mega-fauna, require management. There are many different ways to do this in different areas. These are the questions exercising many applied ecologists and animal welfare scientists.

Although Treves et al.'s points about justice for all living things are worth making, time is running out. If we are going to contribute in any way to help with these problems, we must produce well thought out proposals that are practical and realistic. One suggestion is to extend the baseline idea of the human bill of rights: "freedoms" for all living things. Here, although also full of anthropocentric political concerns, the basic needs common at least to all mammals are stated. These include: access to sufficient food, water, shelter and an ability to exercise choices. How this is to be achieved for the (a) ecosystem, (b) the different species or (c) the individual in each case needs careful consideration.

In her commentary, Alexander (2019), writing that "there are adequate human capacities for making judgements about animals' welfare," thereby provides an example of the anthropocentricity inherent in all the commentaries. How on earth can judgements be made about another species' world-view and hence their quality of life unless we begin to study it directly? Today we only think from the human perspective. Curious too is the belief of commentator Baker (2019) that by empowering all (who? only humans? sentient beings? or plants too?), the loss of biodiversity will be stemmed. Humans, like any other species, will continue to butter their own bread - although in their case, they know full well the consequences of their actions, whether they be meat-eaters, vegetarians or vegans. For example, they continue to expand and take cheap planes for holidays, drive around in cars, consume more and more unnecessary products. These include products that are "organically produced," which threaten populations (e.g., organic soya milk or palm oil); or that cause extinction of species by the thousand (e.g., vegetable production using absurd energy ratios: 1 calorie produced for every 10 used, and often a range of lethal chemicals and over-fishing); or cause whole populations to suffer (e.g., intensively raised beef, chickens and pigs).

There is anthropocentricity in assuming that other species cannot be moral agents. Do no nonhumans have any idea about the rights and wrongs of behavior? If this is NOT the case, then how is voluntary learning possible? How do social species organize their societies, with social contracts? Then there are all the other "mental skills" that are supposed to be (almost) unique to humans such as "theory of mind," "self-awareness" ideas about the past and future, not to mention a whole raft of emotions. Anthropocentric beliefs are increasingly open to question. Yes, nonhumans tend not to use context-independent language (although they can learn to comprehend it), but this can be thought of as an advantage, opening the mental doors to different types of thinking that are otherwise suppressed by the symbolic thinking of human language and the subsequent development of human technology.

Unmentioned too are many questions about whether economic gain and "development" are desirable or necessary to build a sustainable world that will increase the quality of life for all. It seems clear that to make any progress in either "conserving" or "preserving" the natural world, we have to find a way to use empirical data and subjective experiences complementarily to understand the wholeness of nature (Bortoft 1988) rather than continuing to chase each other's tails in search of technological or judiciary solutions. 


\section{References}

Alexander, S. M. (2019) Reconciling just preservation. Animal Sentience 27(6)

Baker, L. (2019) To preserve or to conserve? Animal Sentience 27(7)

Bortoft, H. (1988) The wholeness of nature. Goethe's way of science. Floris Books. Edinburgh

Treves, A., Santiago-Ávila, F. J., \& Lynn, W. S. (2019). Just preservation. Animal Sentience 27(1) 


\title{
Call for Papers
}

\author{
Special Issue of the Journal of Consciousness Studies
}

Plant Sentience: Theoretical and Empirical Issues

Guest Editors: Vicente Raja (Rotman Institute of Philosophy, Western University)

Miguel Segundo-Ortin (School of Liberal Arts, University of Wollongong)

In this special issue, we address the issue of plant sentience/consciousness from different disciplines that combine both theoretical and empirical perspectives. Some of the questions to be addressed in the special issue include the following:

- Plants exhibit interesting behaviors; does this entail that they are conscious to some extent?

- What are the requirements for a living organism to be conscious? Do plants meet these requirements?

- What does the possibility of plant sentience/consciousness entail for the study of the evolution of consciousness?

- Is it just a categorical mistake to attribute consciousness to plants?

- Can we talk about different levels or degrees of consciousness?

\section{How to submit?}

\section{Deadline: June $\mathbf{1}^{\text {st }}, \mathbf{2 0 2 0}$}

Please submit your papers (max. 9000 words including footnotes, references, abstract, etc.) to vgalian@uwo.ca with subject “Paper Special Issue JCS".

For more information, including bibliography and more detailed descriptions of the topics and questions to be addressed in the papers submitted to the special issue, please contact the guest editors at vgalian@uwo.ca (Vicente) or mso693@uowmail.edu.au (Miguel). 